\title{
GTF3C5 wt Allele
}

National Cancer Institute

\section{Source}

National Cancer Institute. GTF3C5 wt Allele. NCI Thesaurus. Code C52632.

Human GT F3C5 wild-type allele is located in the vicinity of $9 q 34$ and is approximately 28 $\mathrm{kb}$ in length. This allele, which encodes general transcription factor $3 \mathrm{C}$ polypeptide 5 protein, is involved in the regulation of the synthesis of transfer RNA, 5S ribosomal RNA and other small RNA types. 